\title{
Quarterly Report on the Strontium Heat Source Development Program, Operations and By-Products Utilization Division for April Through June 1981
}

H. T. Fullam

September 1981

Prepared for the U.S. Department of Energy under Contract DE-AC06-76RLO 1830

Pacific Northwest Laboratory Operated for the U.S. Department of Energy by Battelle Memorial Institute 
This report was prepared as an account of work sponiored by the United States Government. Neither the United 5tates nor the Department of Energy, nor any of theit emplayees, nor any of their contraciors, subcontractors, or their employees, makes any warranty, express or implied, or assumes any legal liability or responsibility for the accuracy. completeness or usefulness of any information, apparatus, product or process disclosed, or represents that its use would not intringe privarely owned rights.

The views, opinions and conclusions contained in this teport are those of the contractor and do not necessarily represent those of the United States Government or the United States Department of Energy.

\author{
PACIFIC NORTHWEST LABORATORY \\ operated by \\ BATTELLE \\ for the \\ UNITED STATES DEPARTMENT OF ENERGY \\ Under Contract DE-AC06-76RLO 1830
}
Primed in the United Srates of America
Available from
National Technical Information Service
United States Department of Commerce
5285 Post Royal Road
Springfield, Virsinia 22151

Pice: Printed Copy s.

4. Mierafiche 53,00

\begin{tabular}{|c|c|}
\hline "Pages & $\begin{array}{c}\text { Nris } \\
\text { Selling Puice }\end{array}$ \\
\hline $001-025$ & 5600 \\
\hline 026.050 & 5450 \\
\hline $051-075$ & 53.25 \\
\hline $026-100$ & $\$ 5.00$ \\
\hline $107-125$ & $\$ 6.50$ \\
\hline $126 \cdot 150$ & 37.25 \\
\hline $151-175$ & $\$ 600$ \\
\hline $376-200$ & 3900 \\
\hline $201 \cdot 225$ & 59.25 \\
\hline $226-250$ & 39.50 \\
\hline 251.275 & 510.75 \\
\hline $276-300$ & $\$ 11.00$ \\
\hline
\end{tabular}


PNL $-1845-51$

33679000516288

UC-23

QUARTERLY REPORT ON THE STRONTIUM HEAT SOURCE DEVELOPMENT PROGRAM, OPERATIONS AND BY-PRODUCTS

UTILIZATION DIVISION FOR

APRIL - JUNE 1981

H. T. Fullam

September 1981

Prepared for

the U. S. Department of Energy

under Contract DE-AC06-76RLO 1830

Pacific Northwest Laboratory

Richland, Washington 99352 


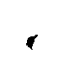


All experimental activities related to the Strontium Heat Source Development Program have been completed. The only remaining activities are preparation and issuance of final reports that summarize program results. This report represents the last of the program quarterly progress reports that will be issued. 
.

.

. 


\section{CONTENTS}

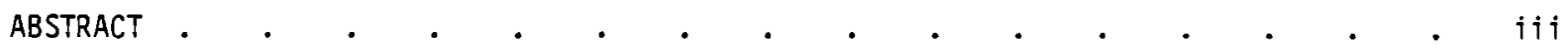

TASK 1 - CHEMICAL AND PHYSICAL PROPERTIES OF $90 \mathrm{SrF}_{2} \quad$ • $\quad . \quad$. $\quad . \quad$. 1

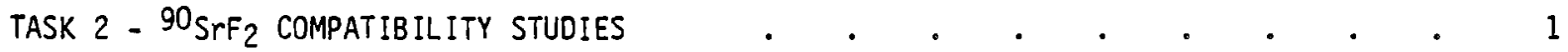

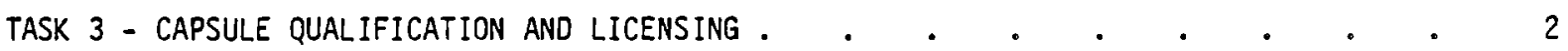

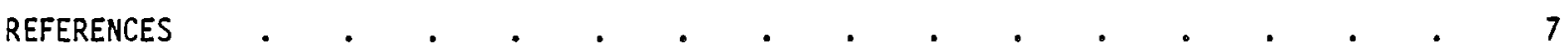


1 Supplemental Qualification Tests for the $90_{S r} F_{2}$ Heat-Source Outer Capsules 3

2 Results Obtained in the Qualification Testing of the As-Fabricated Hastelloy $S$ and Hastelloy $\mathrm{C}-4$ Prototype Outer Capsules

3 Results Obtained in the Qualification Testing of Hastelloy S and Hastelloy C-4 Prototype Outer Capsules Aged at $650^{\circ} \mathrm{C}$ for 8000 Hours.$\quad$..$\quad .5$

4 Results Obtained in the Qualification Testing of Hastelloy S and Hastelloy C-4 Prototype Outer Capsules Aged at $725^{\circ} \mathrm{C}$ for 8000 Hours 


\title{
STRONTIUM HEAT SOURCE DEVELOPMENT PROGRAM
}

\author{
H. H. Van Tuyl, Program Manager
}

H. T. Fullam, Principal Investigator

At Hanford, strontium is separated from the high-level waste, converted to the fluoride, and doubly encapsulated in smal1, high-integrity containers for subsequent long-term storage. The fluoride conversion, encapsulation, and storage take place in the Waste Encapsulation and Storage Facilities (WESF). The encapsulated strontium fluoride represents an economical source of $90 \mathrm{Sr}$ if the WESF capsule can be licensed for heat-source applications under anticipateduse conditions. The objective of this program is to obtain the data needed to 1 icense $90 \mathrm{SrF} 2$ heat sources and specifically the $90 \mathrm{SrF}_{2}$ WESF capsules. The information needed for licensing can be divided into three general task areas:

Task 1 - Chemical and Physical Properties of $90 \mathrm{SrF}_{2}$

Task 2 - $90 \mathrm{SrF}_{2}$ Compatibility Studies

Task 3 - CapsuTe Qualification and Licensing.

Efforts proceeded concurrently on all three tasks to obtain the required information.

All experimental activities related to the three tasks have now been completed. The only remaining activities are to prepare and issue various reports summarizing the results of the various studies. This report represents the last of the series of quarterly progress reports that will be issued on the Strontium Heat Source Development Program.

$\frac{\text { TASK } 1 \text { - CHEMICAL ANO PHYSICAL PROPERTIES OF }{ }^{90} \text { SrF }}{\text { The topical report on the migration of }{ }^{90} \mathrm{Sr} \text { from }}$ been issued.

The updated Strontium-90 Fluoride Data Sheet (Fullam 1981a) has gone to printing and should be issued in August.

TASK $2-{ }^{90}$ SrF $_{2}$ COMPATIBILITY STUDIES

The final report (Fullam 1981b) summarizing all of the ${ }^{90} \mathrm{SrF}_{2}$ compatibility studies carried out during the program has been submitted to the sponsor for review and comment. The results of the studies and the conclusions reached regarding ${ }^{90} \mathrm{SrF}_{2}$ compatibility with containment materials are summarized below.

Results obtained in the strontium fluoride compatibility tests carried out at Pacific Northwest Laboratory show that attack of metallic containment materials at $600^{\circ} \mathrm{C}$ to $1100^{\circ} \mathrm{C}$ is primarily due to fluoride impurities in the strontium fluoride. The fluorides of iron and chromium contribute principally to the metal attack. The data also show that once the critical impurities in the ${ }^{90} \mathrm{SrF}_{2}$ have been consumed by reaction with the metal, the rate of metal attack decreases to a very low level. In general, the critical impurities react with the metal within 6,000 to $12,000 \mathrm{~h}$, and metal specimens exposed to ${ }^{90} \mathrm{SrF}$ for periods of 20,000 to $30,000 \mathrm{~h}$ show no more chemical attack than the specimens tested for 6,000 to $12,000 \mathrm{~h}$. 
Evaluation of the test data show that WESF-produced ${ }^{90} \mathrm{SrF}_{2}$ can be adequately contained for the nominal 10-year service life of a heat source by using Hastelloy C-276, (3) Haynes Alloy 25, (B) or TZM as the primary containment material. However, all three alloys suffer significant attack by the ${ }^{90} \mathrm{SrF}_{2}$ at heat-source operating temperatures, which places certain limitations and requirements on the design and use of the heat source. Thermal aging reactions that affect the microstructure and mechanical properties of Hastelloy $\mathrm{C}-276$ and Haynes Alloy $25 \mathrm{place}$ additional restraints on the heat-source design if either alloy is used in the construction of the heat source. The principal restraints and requirements placed on the heat-source design by ${ }^{90} \mathrm{SrF}_{2}$ compatibility and alloy-aging reactions include:

- The heat source must provide at least double containment of the ${ }^{90} \mathrm{SrF}_{2}$ with the inner capsule fabricated from Hastelloy C-276, Haynes Alloy 25, or TZM.

- The outer capsule(s) of the heat source must provide all of the structural strength needed to meet licensing requirements without support from the inner capsule. The inner capsule should only serve as the primary containment barrier for the ${ }^{90} \mathrm{SrF}_{2}$ since fluoride attack and aging reactions serve to reduce its structural strength. Once the heat source has been at temperatures of $600^{\circ} \mathrm{C}$ or higher for an extended period of time, mechanical stressing of the inner capsule could result in its fracture and release of radioactivity.

- If Hastelloy C-276 or Haynes Alloy 25 is used as the inner capsule material, the capsule $/{ }^{90} \mathrm{SrF}_{2}$ interface temperature should be limited to a maximum of $800^{\circ} \mathrm{C}$. If TZM is used for the inner capsule, the interface temperature should be limited to $1000^{\circ} \mathrm{C}$. If TZM is used, assurance must be provided that the inner capsule is protected from external oxidation.

- The service life of the heat source should be limited to 10 years if Hastelloy C-276 or Haynes Alloy 25 is used for the inner capsule, and 20 years if TZM is used.

Because iron and chromium fluorides in the ${ }^{90} \mathrm{SrF}_{2}$ are principal causes of metal attack, operational changes at WESF that reduce their concentrations in the fluoride would improve the compatibility of the ${ }^{90} \mathrm{SrF}_{2}$ with containment materials in heat-source service. Replacement of the Incone $1^{(0)}$ boats used in firing the ${ }^{90} \mathrm{SrF}_{2}$ with a more corrosion-resistant material, or a material free of iron and chromium, should serve to effectively reduce the iron and chromium content of the ${ }^{90} \mathrm{SrF}_{2}$.

\section{TASK 3 - CAPSULE QUALIFICATION AND LICENSING}

All qualification testing of the as-fabricated and thermally aged capsules has been completed. Each of the 15 Hastelloy $S$ and seven Hastelloy C-4 prototype outer capsules was subjected to one primary and four secondary qualification tests. In addition, selected capsules were subjected to three supplemental tests. The supplemental tests, described in Table 1 , are

(B) Cabot Corp., Kokomo, Indiana.

(i) Cabot Corp., Kokomo, Indiana.

(B)Hunt ington Alloys, Inc., Huntington, West Virginia. 
TABLE 1. Supplemental Qualification Tests for the $90 \mathrm{SrF}_{2}$ Heat-Source Outer Capsules

1. Supplemental Pressure Test

The heat-source outer capsule shall not leak at a rate greater than $1 \times 10^{-8} \mathrm{~cm}^{3} / \mathrm{s}$ after being subjected to an external hydrostatic pressure of 24,000 ps $i$, or the pressure at which the capsule collapses, whichever is lower.

2. Supplemental Percussion Test

The capsule shall not leak at a rate greater than $1 \times 10^{-8} \mathrm{~cm}^{3} / \mathrm{s}$ after being struck by the flat face of a 2.5-cm-dia ( $1-i n$.$) steel billet with an impact energy equivalent$ to $20 \mathrm{~kg}-\mathrm{m}$ ( $\sim 145 \mathrm{ft}-1 \mathrm{~b})$. The billet edges shall be rounded off to a radius of not less than $3 \mathrm{~mm}$, and the capsule shall rest on a lead sheet equal to or less than $25 \mathrm{~mm}$ thick with a Brinell hardness of 3.5 to 4.5 . The lead sheet shall cover a greater area than the capsule and shall rest on a smooth, solid surface. A fresh lead sheet shall be used for each test, and the capsule shall be struck in such a manner that the maximum possible damage will result.

3. Puncture Test

The capsule shall not leak at a rate greater than $1 \times 10^{-8} \mathrm{~cm}^{3} / \mathrm{s}$ after being struck by a 3-mm-dia pin rigidly attached to a $2.5-\mathrm{cm}-d i a$ steel billet, with an impact energy equivalent to $1 \mathrm{~kg}-\mathrm{m}$. The pin shall be $6 \mathrm{~mm}$ long and machined from one end of the steel billet. The impact end of the pin shall be hemispherical. The capsule shall rest on a stee 1 plate at least $1.25 \mathrm{~cm}(0.5 \mathrm{in.})$ thick and which covers an area greater than that of the capsule and which rests on a smooth, solid surface. The capsule shall be struck in such a manner that the maximum possible damage will result.

not currently part of the heat-source licensing requirement, but are requirements defined in ANSI-N542 (Anon. 1977) for sealed radioisotope sources.

The results obtained in the qualification tests are summarized in Tables 2 through 4 . The results show that the as-fabricated and thermally aged Hastelloy $S$ outer capsules passed the primary and secondary qualification tests without difficulty. The capsules also passed the supplemental percussion and puncture tests without problems. The capsules subjected to the supplemental pressure test partially collapsed at a pressure of 24,500 psi. The partially collapsed capsules passed the helium leak test (leak rate $<1 \times 10^{-8} \mathrm{std} \mathrm{cm}^{3} / \mathrm{s}$ ).

The as-fabricated Hastelloy $\mathrm{C}-4$ capsules and the Hastelloy $\mathrm{C}-4$ capsules aged at $725^{\circ} \mathrm{C}$ passed the primary and secondary qualification tests without difficulty. They also passed the supplemental percussion and puncture tests without a problem. The capsules subjected to the supplemental pressure test partially collapsed at a pressure between 20,000 and 21,000 psi. The partially collapsed capsules passed the helium leak test (leak rate $<1 \times 10^{-8} \mathrm{std} \mathrm{cm}^{3} / \mathrm{s}$ ).

The only capsule that failed the qualification tests was the Hastelloy $\mathrm{C}-4$ capsule aged at $650^{\circ} \mathrm{C}$ for $8000 \mathrm{~h}$. The capsule passed the primary pressure and secondary impact and percussion tests, but failed the secondary thermal test. Examination of the capsule showed a crack in one of the seal welds. Destructive examination of the capsule indicated that the crack was initiated by stresses encountered in the impact test and propagated to the point of failure by stresses developed in the thermal test. Micrographs of the seal weld at the point of failure showed that the weld penetration was only $40 \%$ of the required $0.10 \mathrm{in}$. The results of the other tests with Hastelloy C-4 indicate that use of a full-penetration seal weld would eliminate the problem.

A final report summarizing all of the Task 3 activities is now being prepared (Fullam 1981C). 
TABLE 2. Results Obtained in the Qualification Testing of the As-Fabricated Hastelloy $S$ and Hastelloy C-4 Prototype Outer Capsules

Hastelloy $\mathrm{C}-4$

Qualification Tests

\begin{tabular}{|c|c|c|c|c|c|c|c|}
\hline \multicolumn{5}{|c|}{ Hastelloy S Capsule Number } & \multicolumn{3}{|c|}{ Capsule Number } \\
\hline$s-12(a)$ & $S-13$ & $S-15$ & $S-17$ & $S-20$ & $2(a)$ & 3 & $7 R$ \\
\hline
\end{tabular}

A. Primary Qualification Tests

Impact

Pressure

Percussion

Thermal

Thermal Quench

$\begin{array}{cccccccc}\text { Pass } & - & - & - & - & \text { Pass } & - & - \\ - & - & - & \text { Pass } & - & - & \text { Pass } & - \\ - & - & - & - & \text { Pass } & - & - & \text { Pass } \\ - & - & \text { Pass } & - & - & - & - & - \\ - & \text { Pass } & - & - & - & - & - & -\end{array}$

B. Secondary Qual ification Tests

Impact

Pressure

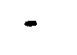

$$
\text { Pass }
$$

Pass

Pass

Pass

-

Pass Pass

Percussion

Pass

Pass Pass

- Pass

Pass

-

Pass

Thermal

Pass

Pass Pass

Pass

$-$

Pass

Pass Pass

Pass

Pass

Pass

Pass

-

Pass

Pass

Pass

Pass

Thermal Quench

Pass

- Pass

Pass Pass Pass

C. Supplemental Tests

Pressure

Percussion

Puncture

$\begin{array}{cccccccc}- & - & P-C^{(b)} & - & - & - & - & P-C \\ \text { Pass } & \text { Pass } & \text { Pass } & - & \text { Pass } & \text { Pass } & - & \text { Pass } \\ - & \text { Pass } & & - & - & - & \text { Pass } & -\end{array}$

(a) Capsule contained a Hastelioy C-276 inner capsule filled with inert SrF 2 .

(b) Some distortion of capsule, but the capsule passed the helium leak test. 
TABLE 3. Results Obtained in the Qualification Testing of Hastelloy S and Hastelloy C-4 Prototype Outer Capsules Aged at $650^{\circ} \mathrm{C}$ for 8000 Hours

Qualification Tests

A. Primary Qualification Tests

Impact

Pressure

Percussion

Therma 1

Thermal Quench

B. Secondary Qual if ication Tests

Impact

Pressure

Percussion

Thermal

Thermal Quench

$$
\text { Hastelloy } 5 \text { Capsule Number }
$$
s-8(a)

S-14

$5-18 \quad 5-22 \quad 5-23$

$\begin{array}{cc}\text { Pass } & - \\ - & - \\ - & - \\ - & \text { Pass } \\ - & -\end{array}$

$\begin{array}{cc}- & \text { Pass } \\ \text { Pass } & \text { Pass } \\ \text { Pass } & \text { Pass } \\ \text { Pass } & - \\ \text { Pass } & \text { Pass }\end{array}$

Pass

Pass

Pass

Pass

Pass

Pass

-

Pass

Pass

Pass

Pass

-

Pass

- Pass Pass

$\begin{array}{ccccc}- & P-C^{(b)} & - & P-C & - \\ - & - & \text { Pass } & - & \text { Pass } \\ - & - & \text { Pass } & - & -\end{array}$

Hastel loy $\mathrm{C}-4$ Capsule No. 4

C. Supplemental Tests

Pressure

Percussion

Puncture

(a) Capsule contained a Hastelloy C-276 inner capsule filled with inert SrF2.

(b) Some distortion of capsule, but the capsule passed the helium leak check. 
TABLE 4. Results Obtained in the Qualification Testing of Hastelloy S and Hastelloy C-4 Prototype Outer Capsules Aged at $725^{\circ} \mathrm{C}$ for 8000 Hours

Qualification Tests

A. Primary Qualification Tests

Impact

Pressure

Percussion

Thermal

Thermal Quench

B. Secondary Qualification Tests

Impact

Pressure

Percussion

Thermal

Thermal Quench

C. Supplemental Tests

Pressure

Percussion

Puncture
Hastelloy 5 Capsule Number

$\underline{S-9(a) \quad S-11 \quad S-16 \quad S-19 \quad S-21}$

Hastelloy $\mathrm{C}-4$

Capsule Number

1(a) $6 \quad 7$

$\begin{array}{cccccccc}\text { Pass } & - & - & - & - & \text { Pass } & - & - \\ - & - & - & \text { Pass } & - & - & \text { Pass } & - \\ - & \text { Pass } & - & - & - & - & - & \text { Pass } \\ - & - & - & - & \text { Pass } & - & - & - \\ - & - & \text { Pass } & - & - & - & - & -\end{array}$

$\begin{array}{cccccccc}- & \text { Pass } & \text { Pass } & \text { Pass } & \text { Pass } & - & \text { Pass } & \text { Pass } \\ \text { Pass } & \text { Pass } & \text { Pass } & - & \text { Pass } & \text { Pass } & - & \text { Pass } \\ \text { Pass } & - & \text { Pass } & \text { Pass } & \text { Pass } & \text { Pass } & \text { Pass } & - \\ \text { Pass } & \text { Pass } & \text { Pass } & \text { Pass } & - & \text { Pass } & \text { Pass } & \text { Pass } \\ \text { Pass } & \text { Pass } & - & \text { Pass } & \text { Pass } & \text { Pass } & \text { Pass } & \text { Pass }\end{array}$

(a) Capsule contained a Hastelloy C-276 inner capsule filled with inert SrF 2 .

(b) Some distortion of capsule, but capsule passed the helium leak check. 


\section{REFERENCES}

Anon. 1977. American National Standard Sealed Radioactive Sources, Classification. ANSI-N542, American National Standards Institute. New York, New York.

Fullam, H. T. 1981a. Strontium-90 Fluoride Data Sheet. PNL-3846, Pacific Northwest Laboratory, Richland, Washington.

Fullam, H. T. 1981b. Compatibility of Strontium-90 Fluoride with Containment Materials at Elevated Temperatures. PNL-3833, Pacific Northwest Laboratory, Richland, Washington (to be issued).

Fullam, H. T. 1981c. Design and Qualification Testing of a Strontium-90 Fluoride Heat Source. PNL-3923, Pac if ic Northwest Laboratory, Richland, Washington (to be issued).

Yabusaki, S. 1981. The Migration of Strontium-90 From a Strontium-90 Fluoride Deep Ocean Source. PNL-3805, Pacific Northwest Laboratory, Richland, Washington. 
. 


\section{DISTRIBUTION}

No. of

Copies

\section{OFFSITE}

A. A. Churm

DOE Patent Division

9800 S. Cass Avenue

Argonne, IL 60439

F. E. Coffman

DOE Office of Advanced Nuclear

Systems and Projects, NE-540

Washington, DC 20545

G. L. Bennett

DOE Space and Terrestrial

Systems Division, NE-543

Washington, OC 20545

B. J. Rock

DOE Space and Terrestrial

Systems Division, NE-543

Washington, DC 20545

J. J. Lombardo

DOE Space and Terrestrial

Systems Division, NE -543

Washington, OC 20545

3 W. C. Remini

DOE Operations and By-Products Utilization Division, NE-320

Washington, DC 20545

J. E. Dieckhoner

DOE Operations and By-Products

Utilization Division, NE-321

Washington, DC 20545

D. J. McGoff

DOE Projects and Technology

Division, NE-323

Washington, DC 20545

W. Savage

DOE Space and Terrestrial

Systems Division, NE-543

Washington, DC 20545

J. M. Maddox

DOE

E201

Washington, DC 20545

C. A. Cooley

DOE Waste Management Division

Washington, DC 20545
No. of

Copies

G. Oertel

DOE Waste Management Division

Washington, DC 20545

D. C. Davis, Jr.

DOE Oak Ridge Operations Office

P. O. Box E

Oak Ridge, TN 37830

W. T. Goldston

DOE Savannah River Operations Office

P. 0. Box A

Aiken, SC 29801

27 DOE Technical Information Center

L. L. Jardine

Argonne National Laboratory

9700 South Cass Avenue

Argonne, IL 60439

R. T. Huntoon

E. I. duPont deNemours and Company

Savannah River Laboratory

Aiken, SC 29801

E. H. Cooke-Yarborough

Electronics and Applied Physics Division

Building 347.3, AERE Harwell

Oxfordshire OXI1 ORA

GREAT BRITAIN

S. E. Bronisz

Los Alamos Scient if ic Laboratory

P. 0. Box 1663

Los Alamos, NM 87544

J. S. Sivinski

Division 4535

Sandi a Laboratories

Albuquerque, NM 87185

W. T. Cave

Mons anto Research Corporation

Mound Laboratory (DOE)

Nuclear Operations

P. 0. Box 32

Miamisburg, OH 45342

H. H. Musselman, Tech. Dir.

Department of the Army

Headquarters, U.S. Army

Facilities Engineering Support Agency

Fort Belvoir, VA 22060 
No. of

Copies

Officer in Charge

J. H. Vogt

Naval Nuclear Power Unit

Code 70

Port Hueneme, CA 93043

H. V. Heiss

Code 631

Naval Ocean Systems Center

San Diego, CA 92152

2 A. A. Arcuni

Naval Facilities Engineering Command

Office of Special Assistant -

Nuclear Programs (O4N)

200 Stovall Street

Alexandria, VA 22332

K. W. Haff

Oak Ridge National Laboratory

Oak Ridge, TN 37830

J. Hammond

Oak Ridge National Laboratory

Oak Ridge, TN 37830

J. R. Keiser

Oak Ridge National Laboratory

Oak Ridge, TN 37830

3 E. Lamb

Oak Ridge National Laboratory

Oak Ridge, TN 37830

2 B. J. Tharpe

General Electric Company

Space Division

P. 0 . Box 8661

Philadelphia, PA 19101

2 R. Englehart NUS Corporation

4 Research Place

Rockville, MD 20850

2 P. Dick

Teledyne Energy Systems

$110 \mathrm{~W}$. Timonium Road

Timonium, MD 21093

C. C. Silverstein

Westinghouse Astronuclear Laboratory

P. 0. Box 10864

Pittsburgh, PA 15236
No. of

Copies

ONSITE

3 DOE Richland Operations
D. Bogon
R. E. Gerton
H. E. Ransom

11 Rockwel1 Hanford Operations
H. H. Hopkins
J. D. Kaser
E. J. Kosiancic
T. H. May
K. J. Pascoe
I. E. Reep
P. F. Shaw
J. P. Sloughter
C. R. Stroup
D. D. Wodrich
G. D. Wright

38 Pacific Northwest Laboratory

H. T. Full am (25)

G. L. Long (3)

R. E. Nightingale

L. D. Perrigo

H. H. Van Tuyl

Technical Files (5)

Publishing Coordination EI 